\title{
Current Situation and Countermeasures of Reading Education in China's Colleges and Universities
}

\author{
Li Han \\ Library \\ Qilu University of Technology \\ Jinan Shandong \\ hanli1027@163.com
}

\author{
Jun Liu \\ Faculty of Light Industry \\ Qilu University of Technology \\ Jinan Shandong \\ jun_dongli@163.com
}

\begin{abstract}
Based on the survey and analysis for reading behavior of Chinese students, this paper summarizes the current reading status for Chinese university students, proposes the corresponding countermeasures for existing problems, integrates reading education into university education system, establishes reading credits mechanism, strengthens library' pragmatic function on reading education, founds reading teaching mode, perfects university education system as well as carrying out various formative reading activities.
\end{abstract}

Keywords—China's universities and college; reading; reading education

\section{INTRODUCTION}

Reading is an important approach to acquire knowledge, which is particularly vital importance for the all-round growth of university students[1]. In colleges, reading education can improve the overall quality of students by means of reading, aiming at effective realization of college students' selfeducation, perfection of personal character, improvement of problem-solving abilities to help them set up the correct values and outlook on life and world at large, centering on reading to launch a series of education activities featuring the teaching of reading, reading training and reading attitude culturing to improve the text selection, text comments, reading processmanagement capabilities[2-4].

However, various surveys demonstrate that, students' reading situation is grim, due to deficiencies or dearth in reading education is found in colleges and universities.

\section{MAJOR PROBlems IN THE StUdENTS’ READING}

\section{A. The importance of reading is recognized}

According to the survey, reading is still the priority of college students' extracurricular activities. Their main task is still learning, however, in order to pass different kinds of exams or finish their school, reading naturally becomes the main task for college students. In response to the question "do you think reading is important?", that people who hold the view "very important" and "relatively important" amount to $83.02 \%$ (Fig.1), this data suggests that the vast majority of college students already have clear cognitions about the importance of reading while only few people are not minded to apprehend reading. Meanwhile, it is not difficult to find most people think it essential that by reading the literacy of individuals can be improved, knowledge also can be broadened; in addition, some people believe they can indulge in reading as relaxation.

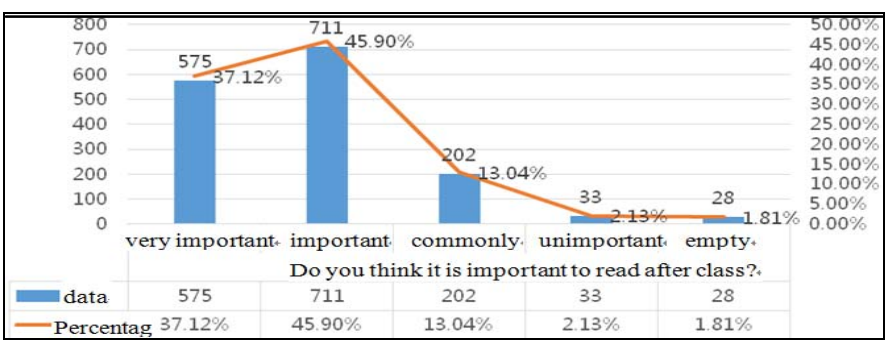

Fig. 1. Do you think it is important to read after class?

\section{B. Reading initiative and time are insufficient}

The survey regarding reading time, as Fig. 2 shows, just $13.49 \%$ of students spend 5 hours above on weekly extracurricular reading on average, $39.19 \%$ of students only 1 2 hours, but $18.4 \%$ of students spend less than 1 hour on reading, this suggests that reading time students have paid is obviously inadequate, lacking reading time makes book reading numbers positively related change, which brings about reading numbers declining along with reading time plummeting, and this phenomenon is more widespread. At the same time, the reasons to interpret are multiple: $37 \%$ students deem that intensive extra-curricular activities take up too much time. Certainly, at present-day, college students' extracurricular lives get more and more diversified and individualized: games, recreations, social networking and other activities are occupying their spare time. Supposing the arrangement on various activities is not plausible, it is bound to result in the consequence these activities will crowd out time for reading. In addition, 36.8\% students believe that their education burden is so heavy that they cannot pay heed to reading. Reading situation of contemporary college students and their understanding of reading vary widely, demonstrating that most college students are aware of the importance of reading though, they are too lazy to read, or read only on the psychological level rather than, pragmatic action, therefore, reading initiative is not strong. 


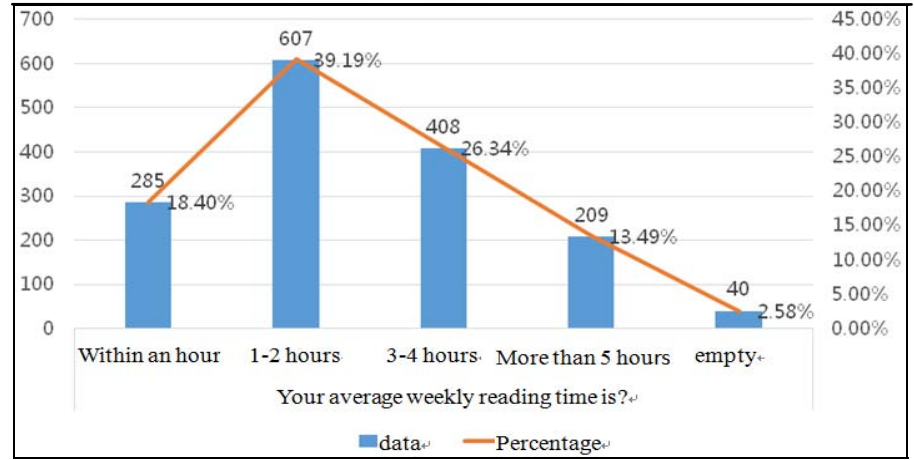

Fig. 2. Your average weekly reading time is?

\section{Comparatively great changes in reading way have taken place}

According to the survey, college students' reading way undergoes great changing, e-reading, as the priority for readers is gradually replacing the original paper reading. E-books featuring large capacity, convenient searching, and portable property make the e-reading available and pretty appealing to university students, and expand the space and channels for reading as well as stimulate interest in reading. With the computers, mobile phones popularizing rate among college students mounting up, e-books and online reading as original channels for reading become more and more popular, the emergence of e-books has begun to challenge the traditional paper books, above all, are stealthily changing the way college students read. As Fig. 3 shows, in response to the question "what's your favorite way of reading", 57\% of the students choose "paper books", 41.96\% respondents select "e-books"; "Online reading" and "We Chat reading" can be classified as e-reading corresponding to the paper reading. Thus, e-reading has become one of the main method of reading for university students, meanwhile, in the survey of book sources, the proportion for college students downloading e-books from the Internet takes account of about $48 \%$, which is almost equal to the proportion of books borrowed from libraries, from this comparison the gradual shift in the reading way can be concluded.

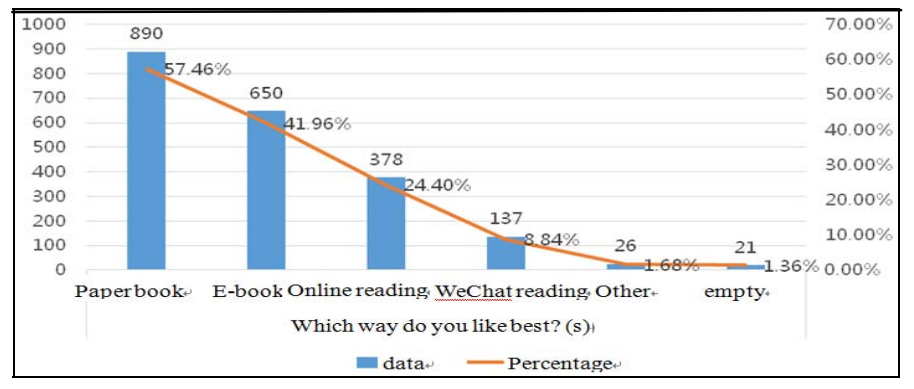

Fig. 3. Which way do you like best?(s)

\section{Reading atmosphere is poor, and students gain less with much confusion}

We can find from the survey, students see the reading atmosphere just so-so, and this proportion is about consistent with students who believe it's good, even quite a of people are discontent with the reading atmosphere. The effect that environment exerts is intangible and everywhere, even penetrate in thought as well as behavior. As a consequence, fine reading environment can help students from the habit of reading; instead, it will whittle the actual effect of reading, even lead to students losing interest in reading. Under the influence of the social environment, under the mounting employment pressure, some college students are worried about the uncertainty of their prospects for living. So some of them struggle for different professional certificates such as certificate of business English, junior accountant certificates, computer certificates; There are quite a number of university students endeavor much efforts for CET-4,CET-6, all these lead to a blundering reading atmosphere on the campus, influence students' reading attitude, even make reading utility too strong. Also we find puzzlements on reading catch students into trouble, students who said "I don't know what can be read" are of majority; They do not know how to select the reading content, and often follow other's opinions, that is, books selected don't suit their interests; Followed by views like "I don't know how to read" and "What's the purpose of reading", these questions illustrate some of the students' awareness of the importance of reading are not sufficient and have a more negative attitude towards reading.

\section{THE CURRENT SITUATION OF CHINESE READING EDUCATION IN COLLEGES AND UNIVERSITIES}

According to the survey, current reading situation in part of some universities can be summed up as follows: insufficient reading initiative, lacking reading time, limited reading content, too strong utilitarianism, less reading gains. Students' reading situation reflects China's higher education concerning reading is inadequate, which means that intensifying the popularization of reading education in China's higher education is of necessity.

\section{A. Little attention has been paid to reading education in some colleges and universities}

In 2016, the number of general undergraduate colleges and universities has reached 1216, including 945 general undergraduate universities and colleges (135 key universities, 662 general universities, 148 private undergraduate colleges), and 271 independent colleges, but most of these universities have overlooked the reading education, because they believe reading education has already been implemented in elementary and middle schools stages, and skills, methods, and capacity of reading have been mastered, so it is no longer needed in colleges. However, under the influence of the examoriented education, reading education hasn't been taken seriously, and students are exposed to text and supplementary books, coupled with the rapid development of network, many students like playing games, reading maps, and indulging in audio and video entertainment, as resulting in quite a few students' lacking of interest in reading, and reading habits are premature, reading ability needs to be improved. Therefore, reading education in university should be given considerable attention, the theory of reading pedagogy should be applied to guide college students how to choose a book, how to read so as to develop college interest in academic research, to cultivate 
their learning attitude, with this method important influence on students' values e exerted.

\section{B. Students lack of knowledge of reading education}

At the present-day, college students are bearing severe employment pressure, and utilitarian purpose of reading is very universal: learning can help them find useful knowledge related to work and ignore the knowledge having nothing to do with the test, although it is possible to realize the importance of reading, in face of enormous realistic pressures, students cannot ponder the significance of reading. In addition, students cultivating program formulated by schools doesn't involve reading education, also students know little about this.

\section{The form of reading education is single}

Reading education is valued by a growing number of colleges and universities, and also is gradually carrying out related activities; however, the study found that these activities did not really reflect the essence of reading education. For example, nowadays, many universities carry out reading activities in annual of "world reading day" with the requirements that students must finish reading a book within a certain time and then to share it in various forms, but the activities' effect is not that obvious and can't get recognition from students most of the time. Since most students participate in these activities just with the idea to complete a task, and don't experience the meaning of activities, activities become formalistic. At present, the reading education mainly exists in the form of the student activity as a part of the extracurricular activities of the students instead of integrating into the education system in colleges and universities.

\section{THE IMPLEMENTATION STRATEGY OF READING EDUCATION IN COLLEGES AND UNIVERSITIES}

Talent training in colleges and universities should not only focus on the students' knowledge and skills, but also on the methods of self-learning, and the ability to extrapolate, while strengthen the education of college students' reading is an effective training tool[5-7].

\section{A. Integrating into the colleges and universities education system and establish reading credit mechanism}

It is entailment for the reading education to be included in the education system of colleges and universities. As far as the present reading situation of college students is concerned, there are some disadvantages existing in reading education, which need to be amended in the stage of higher education, so as to promote the effect of reading education in universities. Therefore, we need to add the reading module in the system of higher education, enact some relevant policies, establish the reading credit mechanism, and take the reading quality as student assessment indicators. Credit mechanism is conducive to mobilizing the enthusiasm of reading, initiative, ensuring the orderly conduct of reading education. For example, South Korea's Jiangyuan University undergraduate graduation qualification certification system has linked the reading effect to graduate, among domestic colleges and universities, in Zhejiang University of Finance and Economics, students have "reading 100 book credits certification"; Chongqing Normal University founded "the reading credits", Xiangfan College is carrying out "students' extracurricular reading scores". Such methods can be applied to assess the reading ability of college students [8].

\section{B. To strengthen the library as a reading education practice position}

Library plays a very important role in launching college students reading education, so it must be made full use. First, librarians are supposed to constantly analyze students' reading traits and needs, from the perspective of their interest and professional need; they can enrich the library literature, adjust the stock structure and update the library books. Second, as the reading method changes, the library should also make the best of Internet tool and resources to provide more abundant electronic literature resources and accurate searching guide system, on the other hand, it can aid students to learn and master the scientific using methods for searching tools so as to improve the ability to utilize resources effectively as well as decrease time for researching. Third, a contingent of top-notch teachers for reading education is necessary to be founded in library, moreover, librarians participating in should be full of innovation and love the cause of library, they can be adept to apply the information technology to library work. At the same time, library ought to formulate a long-term plan for cultivating reading education teachers, and by force of professional training, participating in seminars, experiencesharing with some outstanding college libraries, we can improve the guiding level for reading education. Fourth, coupled with the realities and development needs of colleges, library can popularize the information in time, organize different kinds of reading education speeches and training to make students not only obtain knowledge by self-learning, but also improve self-quality.

\section{Creation the reading teaching model to improve the education system in universities}

Reading education is a system engineering, which is not just to set up reading classes, but incorporate it into other classes such as elective, general courses and compulsory courses etc., through these course we can develop students' reading literacy[9].

First, offering a series of courses in reading education. According to different grades and students' needs, we can offer different-level reading education courses. Such as: for the grade one students, new lectures on library training and library resources can be delivered; For graduates, information resources researching and utilization, graduate thesis seminars also can be included; For students with special needs, separate reading guidance classes is necessary, in addition, public courses for fast reading training, reading and appreciation will do good to guide students' independent and efficient reading.

Second, incorporate reading education into other public courses. Among freshmen and sophomores we can open public elective courses in general education, particularly for students majoring in science and engineering with "College Chinese Language and Literature" course, and provides science and 
engineering students with humanities or arts courses with credit requirements. General education courses are mainly classified into the social sciences, philosophy and psychology, Linguistics, literature and the arts, history, mathematics and natural science, and all of them which are non-utilitarian, nonprofessional and non-occupational will improve the students' overall quality in moral and aesthetic education.

Third, starting professional reading courses. Professional reading is one of the main means of realizing professional learning, accumulating professional knowledge as well as the basis of cultivation of college students' professional abilities. Professional reading includes in-class reading materials and extracurricular reading of books. Currently, college students have paid little attention to textbooks' using, and less reading of professional reference books, which will cause effective interaction between students and teachers, is unable to carry out, affecting the effectiveness of teaching and learning at large. Therefore, university teachers should enhance instruction on students' reading. On the one hand, the teachers need to help students to form the habit of reading textbooks, for as much as textbooks are the basis for students' learning, and the depth of reading absolutely will influence the systematic study of professional knowledge. In this regard, teachers should arrange some course-previewing tasks for students and in the classroom, analysis and discussion of some questions can be unfolded to spur on students' autonomous learning and thinking, improving their using times of textbooks. On the other hand, teachers should help students to expand the range of extracurricular reading. After being familiar with the textbooks, teachers can provide the reference reading lists for this course, then require students to finish the time-limited reading, what's more, they can question some students in class in respect of corresponding contents to check whether students have read, how they understand the ideas in the books and whether they can put up with own opinions and so on. That is to say, objective assessment of effect on reading education does promote reading education aims coming true.

\section{To develop a variety of reading and cultural activities to enrich students' lives}

Colleges and universities are expected to develop a wide variety of cultural activities and encourage students to participate in. Various reading and cultural activities are an effective way to develop students' reading education. First of all, reading guidance seminars should be regularly organized. Some experts and scholars can be invited to give reading presentations, thus, reading interpretation from experts coupled with guidance on the s of special topic, will do much to stimulate students' interest in reading, conducive to guide them to broaden their reading vision, even grasp the correct method and direction of reading. Secondly, the review activities are regularly organized. Vivid book reflection and wise book reviews can make students improve reading in the subtle taste by multidimensional display like school radio, newspapers, websites. Now, especially when the Internet is in the prevalent momentum, we are able to use the campus network platform purposefully and systematically to launch online books review activity according to students' needs. With this method, readers' participation in the online e-review will fully attract college students, and cheer them on reading more books, reading good books. Thirdly, the guidance for campus reading association. Campus reading association can make club activities combine with the reading guidance so as to nurture more students regarding reading as a fun and pursuit, through book clubs, the weekend movies, resources sharing and Internet chat platforms as well as a variety of daily activities such as competitions.

\section{CONCLUSION}

Reading education plays an important role in education teaching activities. Currently, when in face of prevailing online reading, how to improve college students' reading literacy, guide them learning to read and read good books need multilevel collaboration of teaching management sector, library, teaching departments, and departments of student affairs as well as frontline teachers, and full scope to respective education functions needs to be devoted to effectively integrate education resources so that students reading education can get the sustainable development.

Project source: 2016 Universities and Colleges Humanities and Social Sciences Research Project in Shandong Province 'Research on Intellectual Women' Reading Orientation and Quality Improvement" (J16WJ10)

\section{REFERENCES}

[1] S Q Wang, Education in Reading.M. Shenyang: Liaoning University Publishing House, 1992,pp. 145.

[2] H Q Wang, Exploration and Practice of University Library to Establish A Long-Term Reading Education Mechanism .J.University Library Working, vol. 2, pp. 85-86, 2011.

[3] W H Luo, Exploration of Structure General Undergraduate Colleges Reading Education System.J.Agriculture Library Intelligence Academic Periodical, vol. 3, pp. 144-147, 2015.

[4] N Zhao, Engineering Students' Information Literacy Education Curricula System Construction. J. Library Forum, vol. 2, pp. 147-148, August 2009.

[5] Margaret, Miller. Culture and Commitment.M. Hebei People's Publishing House, 1987.

[6] Z L Hu, Role-Playing of Digital Library in the Information Quality Education in Colleges and Universities. J. Journal of Academic Theory, vol. 9, pp. 210-213, August 2010.

[7] X L Liu, On education informatization and training for the college students' information quality.J. Nuclear Power Engineering, vol. 31(2), pp. 3693-3696, 2010.

[8] Wang Huiqiu, Chen Minghua, Sun Zhimei. College Graduate Certificate System and Operation---A Creative Reading Education Promoting Mechanism for College Students. J. Library Magazine, vol. 11, pp. 4345, 2008.

[9] J Z L Zhang, Analysis of the influencing factors of College Students' information cognition under the new media environment Based on the Analytic Hierarchy Process. J. Journal of Modern Information, 2013. 